\title{
The effect of Leiber Beta-S on selected immunity indicators in calves
}

\author{
Roman Wójcik \\ University of Warmia and Mazury in Olsztyn, Faculty of Veterinary Medicine, \\ Department of Microbiology and Clinical Immunology, Olsztyn, Poland
}

Received July 15, 2013

Accepted January 23, 2014

\begin{abstract}
A wide variety of dietary supplements containing polysaccharides are being introduced on the market. One of them is Leiber Beta-S ( $\beta-1,3 / 1,6-\mathrm{D}$-glucan) whose immunostimulatory effects have not yet been fully evaluated, in particular in polygastric animals. The aim of this study was to evaluate the effect of this supplement on selected indicators of cellular and humoral immunity in calves. The experiment was performed on 14 calves aged $30 \pm 2$ days, divided into two equal groups of control and experimental animals. The feed administered to calves of the experimental group was supplemented with Leiber Beta-S at $50 \mathrm{mg} / \mathrm{kg}$ body weight, whereas control calves were administered standard farm-made feed without supplementation. Blood was sampled before the experiment (day 0) and on days 15, 30 and 60 to determine the immunity indicators (proliferative response of lipopolysaccharide- and concanavalin A-stimulated lymphocytes, respiratory burst activity, potential killing activity of phagocytes, gamma globulin concentrations, lysozyme activity, ceruloplasmin activity) and biochemical indicator (total protein concentrations). Diet supplemented with Leiber Beta-S stimulated the immune system of calves. Significant differences between the experimental and the control group were found in lysozyme and ceruloplasmin activity, gamma globulin concentrations, potential killing activity of phagocytes, proliferative response of lymphocytes $(P<0.001)$ and respiratory burst activity of phagocytes $(P<0.05)$. No differences were found in the serum total protein between the experimental and the control group. This study reports for the first time the effect of Leiber Beta-S $(\beta-1,3 / 1,6-\mathrm{D}$-glucan) on selected biochemical and immunity indicators in calves.
\end{abstract}

$\beta-1,3 / 1,6-D$-glucan, humoral and cellular immune response, cattle

Beta-glucans synthesized by prokaryotic and eukaryotic cells have been studied extensively in recent years (Akramiene et al. 2007; Milewski et al. 2007; Wójcik et al. 2007; Wójcik et al. 2008). The main source of $\beta$-glucans are fungi, in particular Basidiomycota and yeasts of the genus Saccharomyces cerevisiae which produce soluble and branched $\beta-1,3 / 1,6-D$-glucans. The molecular structure, type and number of side chains, tertiary structure, molecular mass and solubility of $\beta$-glucans determine their physicochemical and immune properties. Product purity is also an important determinant of $\beta$-glucans' quality and effectiveness. Only pure $\beta$-glucan has immunomodulating effects, and the process of glucan extraction by hydrolysis should yield a minimum of $70 \%$ pure $\beta$-glucan. Unlike whole cells of $S$. cerevisiae yeast and the isolated mannanoligosaccharides, free $\beta-1,3 / 1,6$-D-glucan molecules are able to penetrate the intestinal endothelial barrier with the use of specialized surface epithelial (M) cells. In gut-associated lymphoid tissue (GALT), $\beta$-glucans act as antigens by stimulating specific macrophage receptors (Engstad and Robertsen 1993).

Disease and death of calves in the first weeks post partum generate the greatest financial losses in cattle breeding. Most diseases are caused by respiratory and gastrointestinal infections as well as non-infectious factors such as the season of birth, low birth weight, unsupportive environment or failure to supply the calf with colostrum within the recommended time after birth. The most serious health risks are posed by diarrhoea (more than $50 \%$ of calf deaths) caused by infectious factors (Escherichia coli, Salmonella,

Phone: (+48 89) 52332 17; 5233454

Fax: (+48 89) 5234115

E-mail: brandy@uwm.edu.pl

http://actavet.vfu.cz/ 
Clostridium, rotaviruses and coronaviruses) and non-infectious factors (poor hygiene, feeding the milk of cows diagnosed with mastitis, low quality of milk replacers), bronchial pneumonia (caused by more than 10 viruses as well as mycoplasma and chlamydophila bacteria), and calf diphtheria (caused by Bacillus necrophorus that abundantly colonizes soil and fertilizers). Treatment is difficult and prognosis is doubtful, which is why a preventative use of biostimulators, including Leiber Beta-S which contains $80 \%$ pure $\beta-1,3 / 1,6-\mathrm{D}$-glucan, is recommended to mobilize the immune system. Its activity has been tested on selected animal species (Siwicki et al. 2011; Frericks 2013), but to date, the product effectiveness has not been investigated in cattle, in particular in calves.

The aim of this study was to evaluate the effect of feed supplementation with Leiber Beta-S on concentrations of total proteins and selected immunity indicators in calves.

\section{Experimental design}

\section{Materials and Methods}

The experiment was carried out on 14 one-month-old Polish Holstein-Friesian calves (including 7 males and 7 females) in July and August 2011 at a private farm in Księży Dwór, Poland. The calves were administered colostrum at the amount of $2 \mathrm{~kg} / \mathrm{animal} /$ day from $1 \mathrm{~h}$ after birth to 5 days of age. After that, the animals were fed the Polmass Mlekowit milk replacer (a standard farm-made diet) at the amount of 4 liters/day/animal in two portions until the age of 8 weeks. The animals had unlimited access to solid feed (maize silage, meadow hay and Jösera Kälberkost prestarer). Fresh water was supplied ad libitum throughout the experiment. At the age of 1 month, the animals were weighed and divided into two groups (control and experimental) by the analog method. The feed administered to calves of the experimental group was supplemented with Leiber Beta-S ( $\beta$-1,3/1,6-D-glucan) (Leiber $\mathrm{GmbH}$, Bramsche, Germany) at $50 \mathrm{mg} / \mathrm{kg}$ body weight/day, whereas control calves were administered standard farm-made feed without supplementation. At the beginning of the experiment (day 0 ) and on days 15, 30 and 60, blood was sampled from the jugular vein of calves to determine biochemical and immunity indicators.

\section{Cellular immunity indicators}

The metabolic activity of blood phagocytic cells was determined based on measurements of intracellular respiratory burst activity after stimulation with phorobol myristate acetate, (Sigma, USA) based on the method developed by Chung and Secombes and modified by Siwicki et al. (2004). The potential killing activity of mononuclear phagocytes and polymorphonuclear phagocytes was determined in isolated blood leukocytes stimulated with killed microorganisms, according to the method by Siwicki et al. (2004).

The proliferative response of blood lymphocytes after stimulation with mitogens, concanavalin A (ConA) and lipopolysaccharide (LPS) was determined by the methylthiazolyldiphenyl-tetrazolium bromide (MTT) assay that was first described by Mosmann and used in animals by Wagner et al. (1999).

\section{Humoral immunity indicators}

Lysozyme activity in blood plasma was determined by the turbidimetric method developed by Siwicki and Anderson (1993). Ceruloplasmin activity in blood plasma was evaluated by the method proposed by Siwicki and Studnicka (1986), and $\gamma$-globulin concentrations in blood serum were determined by the precipitation method modified by Siwicki and Anderson (1993).

\section{Biochemical indicator}

Concentrations of total proteins in blood serum were determined by spectrophotometry according to the method described by Siwicki and Anderson (1993).

\section{Statistical analysis}

The results were processed statistically by one-factorial analysis of variance in an orthogonal design. The significance of differences $(P<0.05, P<0.01, P<0.001)$ between groups was verified by Student's $t$-test and Bonferroni test with the use of GraphPad Prism 5 software.

\section{Results}

In the evaluated cellular immunity indicators (Table 1$)$, a significant $(P \leq 0.05)$ increase in respiratory burst activity and potential killing activity was observed on days 15 and $30(P \leq$ 0.01 and $P \leq 0.001$, respectively), and a significant $(P \leq 0.001)$ increase in the proliferative response of lymphocytes stimulated with lipopolysaccharide (B lymphocytes) and ConA (T lymphocytes) was noted on days 15, 30 and 60 in animals from the experimental group 
Table 1. The effect of Leiber Beta-S on selected indicators of cellular immunity in calves.

\begin{tabular}{lccccc}
\hline \multirow{2}{*}{\begin{tabular}{l} 
Indicator \\
\cline { 2 - 5 }
\end{tabular}} & Group & 0 & \multicolumn{4}{c}{ Experimental day } \\
\cline { 2 - 5 } $\begin{array}{l}\text { Respiratory burst activity } \\
\text { (OD 620 nm) }\end{array}$ & Control & $0.37 \pm 0.07$ & $0.33 \pm 0.08$ & $0.37 \pm 0.04$ & $0.29 \pm 0.06$ \\
\cline { 2 - 5 } $\begin{array}{l}\text { Potential killing activity } \\
\text { (OD 620 nm) }\end{array}$ & Coxperimental & $0.32 \pm 0.06$ & $0.42 \pm 0.05^{\mathrm{a}, \mathrm{A}}$ & $0.45 \pm 0.08^{\mathrm{a}, \mathrm{B}}$ & $0.30 \pm 0.05$ \\
\cline { 2 - 6 } $\begin{array}{l}\text { Proliferative response of } \\
\text { lymphocytes (-ConA) }\end{array}$ & Experimental & $0.17 \pm 0.05$ & $0.25 \pm 0.04^{\mathrm{b}, \mathrm{B}}$ & $0.26 \pm 0.03^{\mathrm{c}, \mathrm{C}}$ & $0.19 \pm 0.01$ \\
\cline { 2 - 6 } & Control & $1.21 \pm 0.18$ & $0.86 \pm 0.12$ & $1.04 \pm 0.22$ & $0.96 \pm 0.10$ \\
\hline $\begin{array}{l}\text { Proliferative response of } \\
\text { lymphocytes (-LPS) }\end{array}$ & Control & $0.94 \pm 0.31$ & $0.81 \pm 0.04$ & $0.96 \pm 0.24$ & $0.93 \pm 0.08$ \\
\cline { 2 - 5 } & Experimental & $1.19 \pm 0.22$ & $1.37 \pm 0.17^{\mathrm{c}}$ & $1.52 \pm 0.21^{\mathrm{c}, \mathrm{A}}$ & $1.22 \pm 0.09^{\mathrm{c}}$ \\
\hline
\end{tabular}

Data are expressed as mean \pm SD. ConA - concanavalin A, LPS - lipopolysaccharide, OD - optical density, ${ }^{\mathrm{a}} P<0.05,{ }^{\mathrm{b}} P<0.01,{ }^{\mathrm{c}} P<0.001$ difference between control group (without supplementation) and experimental group (supplementation with Leiber Beta-S), ${ }^{\mathrm{A}} P \leq 0.05,{ }^{\mathrm{B}} P \leq 0.01,{ }^{\mathrm{C}} P \leq 0.001$ in comparison with day 0 .

Table 2. The effect of Leiber Beta-S on selected indicators of humoral immunity in calves.

\begin{tabular}{|c|c|c|c|c|c|}
\hline \multirow{2}{*}{ Indicator } & \multirow{2}{*}{ Group } & \multicolumn{4}{|c|}{ Experimental day } \\
\hline & & 0 & 15 & 30 & 60 \\
\hline \multirow{2}{*}{$\begin{array}{l}\text { Lysozyme activity } \\
(\mathrm{mg} / \mathrm{l})\end{array}$} & Control & $0.51 \pm 0.17$ & $0.33 \pm 0.09$ & $0.38 \pm 0.12$ & $0.41 \pm 0.09$ \\
\hline & Experimental & $0.48 \pm 0.12$ & $0.57 \pm 0.11^{\mathrm{c}}$ & $0.70 \pm 0.16^{\mathrm{b}, \mathrm{A}}$ & $0.50 \pm 0.08$ \\
\hline \multirow{2}{*}{$\begin{array}{l}\text { Ceruloplasmin activity } \\
(\mathrm{mg} / \mathrm{l})\end{array}$} & Control & $48.43 \pm 4.30$ & $45.20 \pm 2.45$ & $53.03 \pm 8.44$ & $49.31 \pm 2.86$ \\
\hline & Experimental & $49.07 \pm 2.60$ & $52.74 \pm 1.99^{\mathrm{c}, \mathrm{A}}$ & $52.36 \pm 1.98$ & $49.87 \pm 2.15$ \\
\hline \multirow{2}{*}{$\gamma$-globulin levels (g/l) } & Control & $8.17 \pm 0.51$ & $9.09 \pm 1.65$ & $9.07 \pm 0.63$ & $10.34 \pm 0.73$ \\
\hline & Experimental & $7.63 \pm 0.97$ & $10.53 \pm 1.26^{\mathrm{C}}$ & $11.81 \pm 0.72^{\mathrm{c}, \mathrm{C}}$ & $12.92 \pm 0.66^{\mathrm{c}, \mathrm{C}}$ \\
\hline
\end{tabular}

Data are expressed as mean $\pm \mathrm{SD} .{ }^{\mathrm{a}} P<0.05,{ }^{\mathrm{b}} P<0.01,{ }^{\mathrm{c}} P<0.001$ difference between control group (without supplementation) and experimental group (supplementation with Leiber Beta-S), ${ }^{\mathrm{A}} P \leq 0.05,{ }^{\mathrm{B}} P \leq 0.01$, ${ }^{\mathrm{C}} P \leq 0.001$ in comparison with day 0 .

compared to animals from the control group. Cellular immunity indicators increased significantly $(P<0.05, P<0.01, P<0.001)$ in animals from the experimental group on days 15 and 30 compared to day 0 (Table 1 ).

Humoral immunity indicators are summarized in Table 2. Compared to control, a significant increase was noted in animals from the experimental group for these indicators: lysozyme activity on day $15(P \leq 0.001)$ and day $30(P \leq 0.01)$, ceruloplasmin activity

Table 3. The effect of Leiber Beta-S on total protein concentrations in calves.

\begin{tabular}{lccccc}
\hline \multirow{2}{*}{\begin{tabular}{l} 
Indicator \\
\cline { 2 - 5 }
\end{tabular}} & Group & 0 & 15 & \multicolumn{4}{c}{ Experimental day } \\
\cline { 2 - 5 } $\begin{array}{l}\text { Total protein } \\
\text { concentrations }(\mathrm{g} / \mathrm{l})\end{array}$ & Control & $48.29 \pm 2.81$ & $49.66 \pm 4.09$ & $50.27 \pm 3.98$ & $55.89 \pm 6.2$ \\
\cline { 2 - 6 } & Experimental & $46.96 \pm 2.23$ & $51.57 \pm 3.59$ & $52.76 \pm 6.40$ & $56.07 \pm 2.77^{\mathrm{B}}$ \\
\hline
\end{tabular}

Data are expressed as mean $\pm \mathrm{SD} .{ }^{\mathrm{a}} P<0.05,{ }^{\mathrm{b}} P<0.01,{ }^{\mathrm{c}} P<0.001$ difference between control group (without supplementation) and experimental group (supplementation with Leiber Beta-S), ${ }^{\mathrm{A}} P \leq 0.05,{ }^{\mathrm{B}} P \leq 0.01$, ${ }^{\mathrm{C}} P \leq 0.001$ in comparison with day 0 . 
on day 15 ( $P \leq 0.001)$, gamma globulin concentrations on days 30 and $60(P \leq 0.001)$. Compared to day 0 , a significant increase in the experimental group was recorded for lysozyme activity on day $30(P \leq 0.05)$, for ceruloplasmin activity on day $15(P \leq 0.05)$ and for gamma globulin concentrations $(P \leq 0.001)$ throughout the experiment.

Despite a minor increase in total protein concentrations (Table 3 ) in animals from the experimental group compared to control, no significant variations were noted in this biochemical indicator on different days of the experiment. A significant $(P \leq 0.01)$ increase in total protein values was observed only in the experimental group on the last day of the experiment in comparison with day 0 .

\section{Discussion}

Leiber Beta-S was found to exert positive effects on fish (Siwicki et al. 2011) and pigs (Frericks 2013), but its effectiveness in calves has not been investigated to date.

In our study, a $27 \%$ and $22 \%$ increase in respiratory burst activity values and a $32 \%$ and $73 \%$ increase in potential killing activity values were observed in animals of the experimental group on days 15 and 30, respectively, compared to control. Similar growth trends were reported in the author's previous studies where calf diets were supplemented with other products containing $\beta$-glucans: Biolex-Beta HP (Wójcik et al. 2007) and Biolex MB40 (Wójcik 2010). After the administration of whole glucan particles and zymosan in an in vitro study, Qi et al. (2011) observed an increase in the production of reactive oxygen species (ROS) and enhanced phagocytic activity of macrophages and dendritic cells. Borchers et al. (2004) suggested that higher concentrations of phagocytic activity could result from $\beta$-glucan binding by Toll-like receptor 2 (TLR-2), dectin-1, complement receptor 3 (CR3), lactosylceramide (LacCer), scavenger receptors and probably other receptors on macrophages/monocytes and granulocytes, which leads to their activation. The above process leads to chemokinesis, chemotaxis and cell degranulation in phagocytes, leading to increased expression of adhesion molecules on the surface of macrophages, intensified formation of reactive oxygen species, reactive nitrogen species and free radicals, higher concentrations and activity of hydrolytic and metabolic enzymes and induction of inflammatory cytokines (Schepetkin and Quinn 2006; Goodridge et al. 2007; Qi et al. 2011). Beta-glucans enhance the phagocytic activity of leukocytes which constitute the first line of defense against pathogens. Supplementation diet with $\beta$-glucans contributes to effective elimination and degradation of pathogens. Antigens are presented to T lymphocytes, thus further stimulating T-cell-mediated immunity.

In our study, a significant increase in the proliferative activity of B lymphocytes stimulated with LPS (by $69 \%, 58 \%$ and $31 \%$, respectively) and T lymphocytes stimulated with ConA (by 134\%, 167\% and 39\% respectively) was observed in experimental animals compared to control on days 15, 30 and 60, respectively. Wa n g et al. (2008) observed in mice similar increase in the proliferative activity of lymphocytes induced by only three of the tested compounds: Astragalan (extract from Astraglus membranaceus), Lentinan (extract from Lentinula edodes) and Ganoderan (extract from Ganoderma lucidum). S o n ck et al. (2010) evaluated seven $\beta$-glucans of different origin and structure and found out stimulating effects on lymphocyte proliferation in porcine leukocytes (in vitro study) only in three of them (Curdlan - bacteria, Zymosan and $\beta$-glucans produced by Euglena gracilis).

In our study, $\beta$-1,3/1,6-D-glucans stimulated lysozyme activity, ceruloplasmin activity and gamma globulin concentrations. The stimulating effects of Leiber Beta-S were significantly less profound than those noted in the author's previous studies on calves whose diets were supplemented with Biolex-Beta HP (Milewski et al. 2007) and Biolex MB40 (Wójcik 2010). Higher concentrations of IgG secretion and a significant increase 
in gamma globulin concentrations compared to control were observed by Wang et al. (2008) in an in vitro study of murine spleen lymphocytes after the administration of Astragalan, Lentinan and Ganoderan and by Soročinová et al. (2013) in an in vivo study of suckling pigs whose diets were supplemented with $\beta$-glucan (Immunol P). In contrast, Hiss and Sauerwein $(2003)$ did not report an increase in specific antibody concentrations in pigs fed with $\beta-1,3 / 1,6-\mathrm{D}$-glucan after vaccination against the porcine reproductive and respiratory syndrome. It should be stressed that gamma globulins include not only specific antibodies, but also haemaglutinin and haemolysin (first class antibodies that play a very important role in the non-specific humoral immune response). A similar increase in lysozyme activity to that noted in our study was reported by Ząbek et al. (2013) in the blood serum of sheep administered $\beta-1,3 / 1,6-D$-glucan (Biolex ${ }^{\circledR}$-Beta $S$ ). Cleary et al. (1999) demonstrated in mice that serum concentrations of lysozyme do not always increase in response to the administration of $\beta$-glucans. Ząbek et al. (2013) did not observe an increase in ceruloplasmin activity in sheep fed Biolex®-Beta $\mathrm{S}$, whereas Milewski et al. (2013) reported such increase in lambs whose diets were supplemented with $S$. cerevisiae (Inter Yeast S). This could be attributed to the stimulation of proinflammatory cytokines (IL-1, IL-6, TNF- $\alpha$ ) after $\beta$-glucan binding by glucan receptors and the stimulation of acute-phase protein genes in hepatocytes including ceruloplasmin (Schepetkin and Quinn 2006). This is an important observation because the stimulation of acute-phase proteins which determine innate mechanisms of humoral immunity could suggest a quick return to homeostasis.

The noted variations in immune responses of different animal species to products containing $\beta$-glucans indicate that the biological activity of $\beta$-glucans is determined by their origin, structure and purity. Further research is needed to test the effectiveness of $\beta$-glucan supplementation in other animal species.

\section{References}

Akramiene D, Kondrotas A, Didziapetriene J, Kevelaitis E 2007: Effects of $\beta$-glucans on the immune system. Medicina 43: 597-606

Borchers AT, Keen CL, Gershwin ME 2004: Mushrooms, tumors, and immunity: an update. Exp Biol Med (Maywood) 229: 393-406

Cleary JA, Kelly GE, Husband AJ 1999: The effect of molecular weight and beta-1,6-linkages on priming of macrophage function in mice by (1,3)-beta-D-glucan. Immunol Cell Biol 77: 395-403

Engstad RE, Robertsen B 1993: Recognition of yeast cell wall glucan by Atlantic salmon (Salmo salar L.) macrophages. Dev Comp Immunol 17: 319-330

Frericks J 2013: Yeast cells and $\beta$-glucans - Multibiotic factors for successful animal nutrition. All About Feed. Yeast Special. 21-22. Available at: http://www.allaboutfeed.net/Special-focus/Yeast-Special/

Goodridge HS, Simmons RM, Underhill DM 2007: Dectin-1 stimulation by Candida albicans yeast or zymosan triggers NFAT activation in macrophages and dendritic cells. J Immunol 178: 3107-3115

Hiss S, Sauerwein H 2003: Influence of dietary ss-glucan on growth performance, lymphocyte proliferation, specific immune response and haptoglobin plasma concentrations in pigs. J Anim Physiol Anim Nutr 87: 2-11

Milewski S, Wójcik R, Małaczewska J, Trapkowska S, Siwicki AK 2007: Effect of $\beta-1,3 / 1,6-D$-glucan on meat performance and non-specific humoral defense mechanisms in lambs. Medycyna Wet 63: 360-363

Milewski S, Wójcik R, Zaleska B, Małaczewska J, Tański Z, Siwicki AK 2013: Effect of Saccharomyces cerevisiae dried yeast on the meat performance traits and selected indicators of humoral immunity in lambs. Acta Vet Brno 82: 147-151

Qi C, Cai Y, Gunn L, Ding C, Li B, Kloecker G, Qian K, Vasilakos J, Saijo S, Iwakura Y, Yannelli JR, Yan J 2011: Differential pathways regulating innate and adaptive antitumor immune responses by particulate and soluble yeast-derived $\beta$-glucans. Blood 117: 6825-6836

Schepetkin IA, Quinn MT 2006: Botanical polysaccharides: macrophage immunomodulation and therapeutic potential. Int Immunopharmacol 6: 317-333

Siwicki AK, Anderson DP 1993: Immunostimulation in fish: measuring the effects of stimulants by serological and immunological methods. US Fish Wildl Service-IFI, Olsztyn, 1, p. 17

Siwicki AK, Kazuń K, Lepa A, Kazuń B 2011: Influence of 1,3-1,6- $\beta$-D-glucan (Leiber® Beta-S) in diets on the effectiveness of anti-Enteric Redmouth Disease (AquaVac ERM) vaccine in rainbow trout (Oncorhynchus mykiss). Centr Eur J Immunol 36: 212-214 
Siwicki AK, Skopińska-Różewska E, Nartowska J, Małaczewska J, Wójcik R, Sommer E, Trapkowska S, Filewska M, Skurzak H 2004: Effect of Immunostim Plus - a standardized fixed combination of Schizandra chinensis with Eleutherococcus senticosus extracts on granulocytes activity and tumour angiogenesis in mice. Bull Vet Inst Pulawy 48: 489-492

Siwicki AK, Studnicka M 1986: Ceruloplasmin activity in carp (Cyprinus carpio). Bamidgeh 38: 126-129

Sonck E, Stuyven E, Goddeeris B, Cox E 2010: The effect of beta-glucans on porcine leukocytes. Vet Immunol Immunopathol 135: 199-207

Soročinová J, Reichel P, Mudroňová D, Novotný J, Link R, Lešková L, Smaržik M, Seidel H, Húska M, Macák V, Dobolyová S, Kovačocyová K 2013: Beta-glucan feeding effect on biochemical and immune responses in vaccinated and non-vaccinated piglets against proliferative enteropathy. Acta Vet Brno 82: $153-159$

Wagner U, Burkhardt E, Failing K 1999: Evaluation of canine lymphocite proliferation: comparison of three different colorimetric methods with the $\left[{ }^{3} H\right]$-thymidine incorporation assay. Vet Immunol Immunop 70: $151-159$

Wang G, Lin W, Zhao R, Lin N 2008: Effects of six polysaccharides extracted from plants on the immunological cells of mice. Wei Sheng Yan Jiu 37: 577-580

Wójcik R 2010: The effect of brewer's yeast (Saccharomyces cerevisiae) extract on selected parameters of biochemical, humoral and cellular immunity in lambs. Bull Vet Inst Pulawy 54: 181-187

Wójcik R, Małaczewska J, Trapkowska S, Siwicki AK 2007: Influence of B-1,3/1,6-D-glucan on nonspecific cellular defence mechanisms in lambs. Medycyna Wet 63: 84-86

Wójcik R, Milewski S, Małaczewska J, Tański Z, Brzostowski H, Siwicki AK 2008: Defence mechanisms of the offspring of ewes fed a diet supplemented with yeast (Saccharomyces cerevisiae) during pregnancy and lactation. Centr Eur J Immunol 33: 197-201

Ząbek K, Milewski S, Wójcik R, Siwicki AK 2013: Effect of $\beta-1,3 / 1,6-\mathrm{D}$-glucan in diet on productivity and humoral and cellular defense mechanisms in sheep. Acta Vet Brno 82: 141-146 